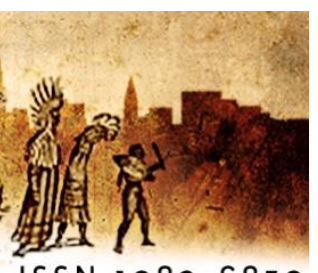

\title{
METÁFORA CRIADORA: \\ UMA PONTE ORTEGUIANA ENTRE FILOSOFIA E LITERATURA
}

Eduardo Cesar Maia F. Filhoi (UFPE)

\begin{abstract}
Resumo:
Este artigo trata da dimensão estético-literária e cognitiva da metáfora no pensamento do filósofo espanhol José Ortega y Gasset. Ortega nunca chegou a sistematizar uma teoria geral da metaforização, mas, em diferentes textos, deixou traços que identificam interessantes caminhos para o estudo da metáfora nas áreas da Estética e da Teoria do Conhecimento. Neste texto, irei me aproximar mais especificamente do campo da Estética; ainda que, em Ortega y Gasset, uma separação categórica e completa entre sua teoria do conhecimento e sua estética - ou entre o literário e o filosófico - seja insustentável, e mais: falsa.
\end{abstract}

PALAVRAS-CHAVE: Ortega y Gasset, Metáfora, Estética, Filosofia.

\begin{abstract}
Resumen:
Este artículo trata de la dimensión estético-literaria y cognitiva de la metáfora en el pensamiento del filósofo español José Ortega y Gasset. Ortega no ha llegado nunca a sistematizar una teoría general de la metaforización; sin embargo, en textos diversos, nos ha dejado huellas que señalan caminos interesantes para el estudio de la metáfora en los terrenos de la Estética y de la Teoría del Conocimiento. En este trabajo, me detendré más específicamente en el ámbito de lo estético, aunque, en Ortega y Gasset, la separación tajante entre su teoría del conocimiento y su estética - o entre lo literario y lo filosófico - sea insostenible, y aún más: falsa.
\end{abstract}

PALABRAS CLAVE: Ortega y Gasset, Metáfora, Estética, Filosofía. 
"Es el hecho siempre irracional del arte, es el absoluto empirismo de la poesía. Cada metáfora es el descubrimiento de una ley del universo"

(José Ortega y Gasset, La deshumanización del arte)

Tomando por referência alguns artigos e ensaios do filósofo espanhol José Ortega y Gasset (1883-1954), e dando ênfase ao seu tão peculiar estilo autoral, é possível vislumbrar, ainda que ele não a tenha sistematizado, uma concepção bastante particular do papel da metáfora na linguagem e no conhecimento. A intensa utilização, em seus textos, de procedimentos metafóricos não reflete somente uma preocupação de ordem retórica ou estilística: em Ortega - assim como na tradição filosófica marginal à qual pertencem pensadores como Leonardo Bruni, Baltasar Gracián, Juan Luis Vives, Lorenzo Valla, Giambattista Vico, Miguel de Unamuno ou María Zambrano -, a criação metafórica apresenta uma dimensão também cognitiva, de investigação da realidade, e, portanto, uma autêntica estatura filosófica.

Ao partir de a prioris filosóficos radicalmente diferentes, a tradição racionalista moderna, que tem origem no pensamento cartesiano, e que exerceu influência hegemônica na filosofia ocidental dos últimos séculos, parte da premissa de que só há verdadeiro pensamento científico se as cadeias dedutivas começam por princípios não derivados, originários. Para filósofos dessa estirpe, as deduções lógicas e a linguagem estritamente racional são as únicas que podem reclamar validade científica e categoria de autêntico conhecimento. Considerada a partir desse paradigma, a linguagem cotidiana, na qual se baseiam nossas frases e nosso comportamento usual e pragmático, e que se serve de imagens, metáforas, analogias etc., não poderia ter pretensões filosóficas e só pertenceria ao âmbito da retórica, do literário, do não-científico. Por isso, os pensadores que reconhecem e utilizam procedimentos retóricos e a linguagem metafórica como autênticas ferramentas filosóficas - elementos fundamentais para uma vertente específica da tradição intelectual humanista - são, muitas vezes, como é o caso do próprio Ortega y Gasset e de sua discípula María Zambrano, considerados exclusivamente literatos, e não propriamente filósofos.

Para o pesquisador e professor da Università degli Studi di Torino Francisco José Martín, "La tradición racionalista siempre ha criticado y rechazado la manera figurativa y Eutomia, Recife, 24(1): 96-107, Set. 2019 
metafórica de expresión por subjetiva, relativa y acientífica" (MARTíN, 1999, pág. 39). Tal negação se deve à consideração de que a metáfora não pode estabelecer uma conexão direta com o real, visto que se caracteriza por ser somente um processo de transferência de significados entre palavras - retórica e poeticamente -, mas não funciona como linguagem explicativa das causalidades e processos da realidade objetiva. No entanto, dentro da tradição humanista de cunho antiplatônico, o processo poético-retórico da metáfora e das analogias são modos de conhecer válidos e úteis, só que possuem uma natureza distinta do conhecimento lógico-formal. Segundo Ernesto Grassi, pensador italiano cujo conjunto da obra é uma tentativa de reabilitar filosoficamente essa vertente marginal do humanismo,

El mundo humano no surge a partir de teorías filosóficas que se derivan racionalmente de primeros principios, sino a partir de acto ingenioso que siempre está confrontado con la situación concreta: rechazaban, pues, la primacía de una filosofía abstracta y del concepto tradicional de pensamiento científico (GRASSI, 1993, pág. 24).

O limite da linguagem racional - supostamente a única rigorosamente filosófica e científica - é que não se fundamenta a si mesma: é um artifício possibilitado pela linguagem figurativa e metafórica. O pensador basco Miguel de Unamuno, por exemplo, costumava ironizar os filósofos que "ingenuamente", segundo ele, negavam o uso filosófico da metáfora. Para o autor de Niebla, tais pensadores simplesmente não se davam conta de que "los que se creen más libres de ella, andan entre sus mallas enredados" (UNAMUNO, 1917, págs. 44-45). Assim, da mesma forma, considerando o pensamento orteguiano, ver-se-á que é tarefa impossível escapar da metáfora em qualquer situação linguística concreta. As palavras nascem como metáforas.

Como dizíamos antes, a perspectiva da tradição racionalista e idealista levou a uma concepção de critério filosófico-científico como rigor formal: o valor de verdade das proposições é garantido pela adequação lógica em relação com as premissas estabelecidas: essas proposições, para serem verdadeiras, além do critério de adequação do dito ao real, devem obedecer a uma dedução lógico-racional, e nenhuma forma de linguagem comum, cotidiana, pragmática ou artístico-literária, que se valha de imagens, analogias e metáforas, pode ter pretensões de conhecimento autêntico. A característica comum a todas essas 
formas de racionalismo é a ambição de, em algum momento, chegar à palavra definitiva: substituir a opinião pelo conhecimento e acabar com o que poderia parecer uma conversação interminável sobre os mesmos temas - embora seja, ironicamente, exatamente o que até hoje foi a filosofia.

Ultrapassar o uso cotidiano e pragmático das palavras e chegar a uma espécie de idioma transcendental (ou uma linguagem ideal, como diriam os positivistas lógicos do século passado), que apresentasse a verdadeira natureza das coisas, da realidade, independentemente de pontos de vista individuais (subjetivos) e dos vocabulários peculiares de cada época, era a máxima pretensão filosófica. As famosas críticas de Platão representante maior da tradição racionalista ocidental - aos poetas e, também, aos retóricos sofistas, fundamentavam-se justamente nesse projeto de atingir uma forma de conhecimento superior, universal e não-contingente. Para chegar a esse grau de conhecimento (episteme) de uma totalidade perfeitamente inteligível e coerentemente organizada, era necessário abandonar a esfera do meramente sensível e transitório. 0 filósofo mostra um desdém pelas aparências porque elas são perecíveis, instáveis e não se deixam aprisionar numa essência inamovível. A filosofia como busca de uma outra forma de razão, a razão poética, preconizada por María Zambrano, uma das principais discípulas de Ortega, nasce dessa constatação e da tentativa superar a contradição entre a beleza da criação poética e a busca da verdade filosófica.

\section{A gravata do filósofo: a metáfora e a tradição intelectual humanista}

No que diz respeito especificamente às contribuições de Ortega y Gasset, é preciso antes de tudo esclarecer que ele não chegou a formatar uma filosofia da metáfora, nem mesmo tratou do tema com exclusividade em algum livro particular, somente em artigos e ensaios esparsos. Contudo, seja em suas intenções retórico-pedagógicas, em suas concepções estéticas ou mesmo em sua teoria do conhecimento, a metáfora aparece como uma ferramenta de conhecimento da realidade, um instrumento, portanto, além de literário, filosófico e científico. 
A filiação orteguiana à tradição humanista - negada por ele mesmo num determinado momento de sua trajetória filosófica - manifesta-se justamente através do lugar e da importância que a metáfora ocupa em seus escritos filosóficos, jornalísticos e críticos. Ortega insistiu sempre no fato de que a plasticidade de sua linguagem, pelo uso de figuras, analogias, ritmo, aliterações e assonâncias, era algo inseparável de seu pensamento conceitual, e foi assim que atuou como jornalista, como ensaísta e como filósofo.

Diversos comentadores já versaram sobre a centralidade que a literatura assume no pensamento e no estilo da prosa de José Ortega y Gasset. Nem sempre esse predicado, no entanto, foi bem entendido - e bem recebido - entre seus pares da filosofia. Uma (falsa) disjuntiva era insistentemente colocada: seria Ortega um filósofo de fato ou "somente" um grande escritor, um excelente ensaísta literário? Num episódio famoso, Ortega declarou: "eso que el señor Prieto considera como una corbata vistosa que me he puesto, resulta ser mi misma columna vertebral que se transparenta" (Obras completas, XI, p. 362)". Tal resposta que, para além de engenhosa, esconde uma significação muito mais profunda do que aparenta à primeira vista foi dada pelo pensador espanhol a um interlocutor que insistia no argumento de que o estilo do autor de La rebelión de las masas não era compatível com a "verdadeira filosofia", porque demasiadamente floreado e metafórico.

Para um de seus principais discípulos, Julián Marías, no pensamento de Ortega a estrutura dramática da linguagem, quer dizer, o estilo e a força narrativa presentes em cada ato de comunicação - seja uma crítica, um ensaio, um livro ou uma simples conversação resultava ser não apenas fator indispensável para sua eficácia retórica, mas também condição essencial para sua verdade. Para compreender, portanto, o caráter particularíssimo do pensamento orteguiano, e sua dupla condição de literato e filósofo, seria preciso levar em consideração que sua maneira de filosofar se dá justamente pela atenção radical à linguagem, através do uso inventivo - analógico e metafórico - das palavras.

Para começar a compreender a visão do pensador sobre o processo metafórico, tomese como exemplo uma expressão bastante comum - fundo da alma. Explica o filósofo:

al decir del alma que tiene fondo, nos referimos primariamente al fondo de un tonel o cosa parecida, y luego, desvirtuando esta primera significación, extirpando de ella toda alusión al espacio corporal, la atribuimos a la psique. Para que haya metáfora, es preciso que nos demos cuenta de esta duplicidad (Obras Completas, II, p. 510). 
O pensador apresenta a metáfora como uma espécie de artifício intelectual que permite que consigamos captar um aspecto da realidade que extrapola os limites de nosso acervo linguístico-conceitual prévio: "Con lo más próximo, y lo que mejor dominamos, podemos alcanzar contacto mental con lo remoto y más arisco. Es la metáfora un suplemento a nuestro brazo intelectivo, y representa, en lógica, la caña de pescar o el fusil" (Obras Completas, II, p. 512). No entanto, não foi tarefa trivial para o autor de España invertebradae este título já é exemplar para o que tratamos aqui - enfrentar toda uma concepção hegemônica de filosofia que partia de premissas radicalmente distintas.

\section{Uma teoria sistemática da metáfora?}

Não é difícil encontrar referências à metáfora em ensaios do filósofo espanhol sobre temas tão diversos como história, matemática, política, arte ou epistemologia. Contudo, em dois de seus textos, a abordagem do tema se faz de forma mais explícita e detalhada. Refirome ao "Ensayo de estética a manera de prólogo" (Obras Completas, I, págs. 664-680), publicado originalmente em 1914; e também ao artigo "Las dos grandes metáforas" (Obras Completas, II, págs. 505-517), de 1924. Em ambos, o procedimento metafórico é tratado desde os pontos de vista da Estética e da Teoria do Conhecimento: Em Ortega y Gasset, a separação absoluta entre esses dois campos da filosofia é algo insustentável e enganoso.

À dimensão estética da metáfora, portanto, Ortega acrescentava a capacidade cognoscitiva: a aptidão criativa de nos levar a conhecer aspectos "dificeis" da realidade que, de outra maneira não nos seria possível. O importante, segundo o filósofo, é que fique claro que essa figura de linguagem tem um papel na poética e outro, completamente distinto, na ciência. De forma contundente, o pensador pontificava: "Cuando un escritor censura el uso de metáforas en filosofía revela simplemente su desconocimiento de lo que es filosofía y de lo que es metáfora" (Obras completas, II, p. 505). O que costuma acontecer - e nisto estaria o problema no âmbito da ciência - é que a metáfora seja tomada não como uma ferramenta científica suplementar, mas como uma forma de pensamento direto, não oblíquo. Dessa 
forma, muitos homens de ciência, sem se dar conta, atuariam, erroneamente, como poetas. Levando em conta essa diferenciação básica.

Para compreender a particular perspectiva a respeito da metáfora desenvolvida por Ortega y Gasset no Ensayo de estética a manera de prólogo é necessário aludir primeiro ao que ele concebia como Eu Executivo: "Yo significa, pues, no este hombre a diferencia de las cosas, sino todo - hombres, cosas, situaciones - en cuanto verificándose, siendo, ejecutándose" (Obras completas, I, pág. 668). Para esclarecer o que diz, Ortega utiliza o exemplo de um homem que, em determinado momento, sente uma dor. Para tal personagem, a dor, naquele instante, é uma realidade em execução, verificando-se. Contudo, se este mesmo homem comunica a outra pessoa aquilo que sente, o que vai receber o outro indivíduo é simplesmente uma imagem da dor alheia, e a imagem da dor de outro, de fato, não dói: "El dolor y el odio ajenos, ¿quién los ha sentido?" (I, pág. 668). Existe, nesta concepção, uma distância clara e intransponível entre o eu e qualquer outra coisa, seja ela um objeto inanimado, um ser vivo ou mesmo algum outro homem.

Mas Ortega tenta não incorrer num simples subjetivismo (ao que costumava criticar como a "enfermedad mental" da Filosofia Moderna):

Cuando yo siento un dolor, cuando amo u odio yo no veo mi dolor ni me veo amando $\mathrm{u}$ odiando. Para que yo vea mi dolor es menester que interrumpa mi situación de doliente y me convierta en un yo vidente. Este yo que ve al otro doliente es ahora el yo verdadero, el ejecutivo, el presente. El yo doliente, hablando con precisión, fue, y ahora es sólo una imagen, una cosa u objeto que tengo delante. (I, pág. 669).

O "yo doliente" se transforma em uma imagem, um objeto. Quer dizer, a única coisa que conseguimos captar a respeito de nosso próprio eu é somente uma imagem, uma projeção. Deduz-se do anterior que tudo o que nós podemos conhecer só o conhecemos através da linguagem, por meio da linguagem: "No puede existir para nosotros nada si no se convierte en imagen, en concepto, en idea - es decir, si no deja de ser lo que es para transformarse en una sombra o esquema de sí mismo" (Obras completas, I, pág. 670).

O eu orteguiano não se encontra isolado, não é o homem que observa as coisas estando afastado delas, senão o homem que sofre a realidade, enquanto a padece - seja essa realidade uma dor, um pensamento ou uma experiência estética. $\mathrm{O}$ eu que nos parece estar 
tão imediatamente próximo a nós mesmos, é só uma imagem do eu e, portanto, o eu de cada um é misterioso até para si, quando o tenta captar com meros conceitos: "La verdadera intimidad, que es algo en cuanto ejecutándose, está a igual distancia de la imagen de lo externo como de lo interno" (Obras completas, I, pág. 670).

Ortega não estava de acordo com a visão muito difundida de que a arte é uma forma de expressar, em sua pureza, a interioridade humana, justamente porque, para ele, essa interioridade não existe per se, independentemente da relação que estabelece com a realidade circunstancial; e, além disso, segundo ele, o que a arte expressa não existia anteriormente, pois os artistas criam objetos novos, e tais objetos viveriam no mundo estético, que é outra forma de realidade.

A partir da ideia de "eu executivo" é que Ortega começa a tratar do lugar da metáfora na linguagem e na arte. Diferentemente da linguagem ordinária, que simplesmente alude às coisas, a linguagem metafórica da arte as efetua. Para tanto, busca, através de um estilo, dar ao que se tenta expressar a aparência de estar "ejecuntándose". Ao contrário da arte, a linguagem corrente, consuetudinária, "hace de todo un fantasma de sí mismo, lo aleja, lo transporta más allá del horizonte de la actualidad" (Obras completas, I, pág. 672). A arte, por sua vez, seria um idioma de signos expressivos que não somente narra as coisas, mas que nos dá a sensação de que apresenta essas coisas em seu processo íntimo, em estado de execução: "El objeto estético es una intimidad en cuanto tal - es todo en cuanto yo" (I, pág. 672). O gozo estético se daria quando temos a forte impressão de que temos em frente a intimidade das coisas, em suas realidades executivas. Trata-se de uma espécie de ilusão consentida, muito próxima da clássica formulação de S. T. Coleridge, que fundamentaria o pacto ficcional e artístico: a suspensão proposital da descrença [willing suspension of disbelief].

Assim, para o filósofo espanhol, a arte se caracterizaria por utilizar a irrealização como meio para a criação de novos objetos estéticos, ou, em outras palavras, os artistas teriam como meta precípua a busca por eternizar o atual, pela absoluta presença, através de uma forma radical de desrealização: a arte. Para Ortega, pois, o instrumento fundamental do procedimento artístico é a metáfora. 
No Ensayo de estética, Ortega y Gasset não se propõe, como já foi dito, a construir uma teoria geral da metáfora, mas é possível extrair do texto algumas concepções que compõem sua compreensão sobre o tema naquele momento. Para ele, "El objeto estético transparenta a sí mismo y encuentra su forma elemental en la metáfora: 'la célula bella'" (Obras completas, I, pág. 673). Diferentemente das definições usuais da figura retórica da metáfora como simples comparação e transferência de sentido entre dois termos, Ortega a compreende como método de criação de objetos novos: "En toda metáfora hay una semejanza real entre sus elementos y por eso se ha creído que la metáfora consistía esencialmente en una asimilación, tal vez en una aproximación asimilatoria de cosas muy distintas" (I, pág. 673). Contudo, para ele, tal entendimento é equivocado porque as semelhanças parciais entre duas coisas não são o importante para a força estética e cognitiva da metáfora. A semelhança positiva é o que sugere a metáfora, o que a possibilita, mas não a define ou a constitui em essência.

O mecanismo metafórico, portanto, funcionaria como uma ferramenta de irrealização: parte-se de una semelhança parcial entre duas coisas e conclui-se por transformá-las em uma coisa nova, de qualidade e natureza diferentes das anteriores. A qualidade de beleza fundamental que o filósofo atribui à metáfora vem do mesmo processo sutil de sua construção: a metáfora confrontaria e testaria os limites da linguagem humana. A operação metafórica faz com que os objetos reais fluam em um puro molde ideal e abandonem seus limites. A coisa real é aniquilada ao se chocar com outra e está apta para receber uma nova forma e estrutura: "Fuera de la metáfora, en el pensar extrapoético, son cada una de estas cosas término, punto de llegada para nuestra consciencia, son sus objetos. Por esto, el ir hacia una de ellas excluye el ir hacia la otra" (Obras completas, I, pág. 675). Por outro lado, dentro da perspectiva orteguiana em relação à linguagem metafórica, a simples acepção etimológica de transferência ou transposição seria extremamente limitada. É condição essencial para que se realize a metáfora que a transferência seja mútua, e mais: não se trata de substituir os lugares entre as duas coisas que se está relacionando, senão de coloca-las em um lugar sentimental, que seria igual para ambas. A ideia de lugar sentimental pode ser considerada, em certo sentido, como uma tentativa incompleta, por parte do filósofo, de esboçar uma espécie de teoria da recepção, no sentido de que os 
sentimentos - entre os quais estão as apreciações de ordem estética - são entendidos como o que uma imagem é como estado executivo, como atuação de um eu.

Em resumo, no que se refere ao processo de construção de um objeto de natureza estética por meios metafóricos, o filósofo afirma que está constituído por partes: a coisa A e a coisa $B$ que

se convierten ahora en meras propiedades de una tercera persona -, el lugar sentimental o la forma yo de ambas. Las dos imágenes dotan al nuevo cuerpo maravilloso de carácter objetivo; su valor sentimental le presta el carácter de profundidad, de intimidad (Obras completas, l, pág. 677).

Dentro da proposta orteguiana apresentada aqui, seria no âmbito da arte, e não no da ciência, onde se faz possível uma aproximação à intimidade das coisas, ao caráter executivo das coisas: onde é mais bem captado, portanto, o dinamismo do real. Assim, a arte pode ser entendida como uma forma de conhecimento que, ainda que seja diferente do saber científico ou filosófico, alcança certas áreas da realidade inatingíveis para estes.

\section{À maneira de conclusão: a força estética e cognitiva da metáfora}

Para finalizar esse breve estudo sobre a metáfora em Ortega y Gasset, e a respeito das relações entre literatura e filosofia em seu pensamento, faz-se necessário, com o fim de entender o uso artístico da metáfora, levar em consideração a diferença fundamental que o pensador estabelece entre as expressões alusivas, quer dizer, a linguagem comum e ordinária, que utiliza as palavras (imagens sonoras e visuais) como forma de expressar "otras imágenes - las cosas, las personas, las situaciones, los sentimientos" (Obras completas, I, pág. 678); e as expressões executivas, as que são utilizadas na arte, e que se valem dos sentimentos executivos para a representação de uma realidade em execução. A arte, para Ortega, tem o poder de efetuar as coisas.

Com esta concepção da estética, Ortega y Gasset buscava superar impasses do subjetivismo idealista moderno, mas sem cair em formas de realismo ou objetivismo ingênuos. Esse projeto, no entanto, não redundou - como em outros pensadores do século 
passado - na negação da centralidade do indivíduo no ato de conhecer; na desconsideração da perspectiva individual como a exclusiva maneira de acessa - e construir - os objetos que compõem a realidade. A contribuição fundamental do pensamento orteguiano em relação a este tema é que, para ele, não seria possível imaginar essa subjetividade pura (à maneira cartesiana), sem relação com as coisas: a subjetividade concebida pelo pensador espanhol a partir de suas reflexões sobre temas artísticos e estéticos, não tem existência em si, isoladamente, como pensava o idealismo moderno, senão que "Esa subjetividad sólo existe en tanto que se ocupa con cosas, que sólo en las deformaciones introducidas en la realidad aparece" (Obras completas, l, pág. 678).

O já mencionado exemplo da "alma-tonel" pode servir aqui para elucidar o procedimento: através da expressão metafórica passamos a perceber como organizável espacialmente algo que, a princípio, não o é; isso abre espaço para uma série de "investigações", inaugurando para nós mesmos a possibilidade de entender a alma - ou recriá-la sob nova clareza, o que talvez equivalha a entendê-la - como tendo um lado esquerdo e um direito, uma entrada e um fundo, conter coisas até o limite como um recipiente que de repente se pode romper ou esvaziar-se... A metáfora, como meio de intelecção, permite um reordenamento das experiências.

Em conformidade com um dos fundamentos da tradição intelectual humanista, no pensamento do autor das Meditaciones del Quijote, a arte transcende o puro esteticismo e pode ser entendida como uma forma autêntica e muito particular de acesso ao real.

\section{Bibliografia}

GRASSI, E. (1993). La filosofía del humanismo: preeminencia de la palabra. Barcelona: Anthropos.

MARTíN, F. J. (1999). La tradición velada: Ortega y el pensamiento humanista. Madrid: Biblioteca Nueva.

ORTEGA Y GASSET, J. (2004). "Ensayo de Estética a Manera de Prólogo" en Obras Completas (OC), Tomo I, pp. 664-68o. Tauros, Madrid. . (2004). "Las dos grandes metáforas" en Obras Completas (OC), Tomo II, pp. 505-517. Tauros, Madrid. 
UNAMUNO, M. (1917). Ensayos. TOMO V (Vol. V). Madrid: Publicaciones de la Residencia de los Estudiantes.

' Professor do curso de Comunicação Social (CAA) e do Programa de Pós-Graduação em Letras (Teoria da Literatura) da Universidade Federal de Pernambuco. 